\title{
Economic Analysis For Conceptual Design of Oxygen-Based PC Boiler
}

Topical Report

Andrew Seltzer

February 2005

DE-FC26-03NT41736

Task 5

Foster Wheeler Power Group, Inc.

12 Peach Tree Hill Road

Livingston, New Jersey 07039 


\section{DISCLAIMER}

This report was prepared as an account of work sponsored by an agency of the United States Government. Neither the United States Government nor any agency thereof, nor any of their employees, makes any warranty, express or implied, or assumes any legal liability or responsibility for the accuracy, completeness, or usefulness of any information, apparatus, product, or process disclosed, or represents that its use would not infringe privately owned rights. Reference herein to any specific commercial product, process, or service by trade name, trademark, manufacturer, or otherwise does not necessarily constitute or imply its endorsement, recommendation, or favoring by the United States Government or any agency thereof. The views and opinions of authors expressed herein do not necessarily state or reflect those of the United States Government or any agency thereof. 


\section{ABSTRACT}

The objective of the economic analysis is to prepare a budgetary estimate of capital and operating costs of the $\mathrm{O}_{2}$-fired PC power plant as well as for the equivalent conventional PC-fired power plant. Capital and operating costs of conventional steam generation, steam heating, and power generation equipment are estimated based on Foster Wheeler's extensive experience and database. Capital and operating costs of equipment, such as oxygen separation and $\mathrm{CO}_{2}$ liquefaction, are based on vendor supplied data and FW process plant experience. The levelized cost of electricity is determined for both the air-fired and $\mathrm{O}_{2}$-fired power plants as well as the $\mathrm{CO}_{2}$ mitigation cost. An economic comparison between the $\mathrm{O}_{2}$-fired $\mathrm{PC}$ and other alternate technologies is presented. 


\section{Table of Contents}

$\begin{array}{cc}\text { ABSTRACT } & \text { Introduction } \ldots \ldots \ldots \ldots \ldots \ldots \\ 2.0 & \text { Executive Summary } \ldots \ldots \ldots \ldots \ldots \ldots\end{array}$




\section{List of Tables}

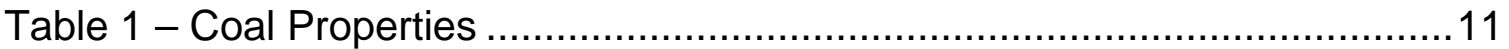

Table 2 - Oxygen-Fired PC Plant Capital Cost Estimate ..................................12

Table 3 - Operating, Maintenance and Fuel Costs for the $\mathrm{O}_{2} \mathrm{PC}$ and the Air-fired

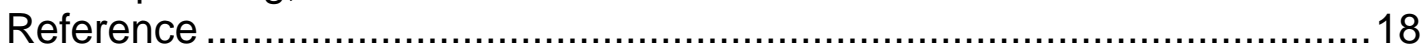

Table 4 - Estimate Basis/Financial Criteria for Revenue Requirement Calculations: Air-fired Reference Plant ..................................................19

Table 5 - Estimate Basis/Financial Criteria for Revenue Requirement Calculations: $\mathrm{O}_{2}$-fired Reference Plant .............................................20

Table 6 - Capital Investment and Revenue Requirement Summary: Air-fired Reference Plant 21

Table 7 - Capital Investment and Revenue Requirement Summary: $\mathrm{O}_{2}$-fired Plant 22

\section{List of Figures}

Figure 1 - Comparison of Levelized Cost of Electricity Among Alternative

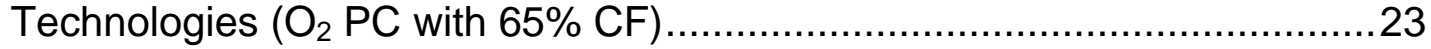

Figure 2 - Comparison of Mitigation Costs Among Alternative Technologies $\left(\mathrm{O}_{2}\right.$ PC with 65\% CF) ........................................................................23

Figure 3 - Comparison of Levelized Cost of Electricity Among Alternative Technologies $\left(\mathrm{O}_{2}\right.$ PC with 85\% CF) .................................................24

Figure 4 - Comparison of Mitigation Costs Among Alternative Technologies $\left(\mathrm{O}_{2}\right.$

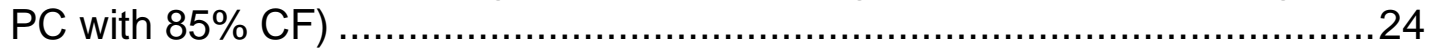




\subsection{Introduction}

This report describes the results and conclusions of Task 5, economic analysis of the Conceptual Design of Oxygen-Based PC Boiler study. The objective of the Conceptual Design of Oxygen-Based PC Boiler study is to develop a conceptual pulverized coal (PC)-fired power plant, which facilitates the practical capture of carbon dioxide capture for subsequent sequestration. The economic analysis is based on the results of the system analysis and design task (Task 2) and the furnace design and analysis task (Task 4). The basis of the economic analysis is conventional air-fired power plant that Foster Wheeler is currently designing and constructing. 


\subsection{Executive Summary}

The objective of the Conceptual Design of Oxygen-Based PC Boiler study is to develop a conceptual pulverized coal-fired power plant, which facilitates the practical capture of carbon dioxide capture for subsequent sequestration. The objective of the economic analysis is to prepare a budgetary estimate of capital and operating costs of the $\mathrm{O}_{2}$-fired PC power plant as well as for the equivalent conventional PC-fired power plant.

The reference plant applied is a subcritical pressure, natural circulation boiler firing high-volatile bituminous coal generating $450 \mathrm{MWe}$. A conventional air-fired case was simulated as the comparison basis.

The economic analysis was carried out based on the EPRI Technical Assessment Guide (TAG) methodology. Plant capital costs were compiled under the Code of Accounts developed by EPRI. The estimate basis is 2004 dollars, 20 -year life, and $85 \%$ capacity factor.

The major changes to the reference plant were redesigned boiler, SCR system removal, FGD removal, ASU addition, and $\mathrm{CO}_{2}$ compression addition. The estimated cost of the reference plant is $\$ 585,000,000(1300 \$ / \mathrm{kW})$ and of the $\mathrm{O}_{2^{-}}$ fired plant is $\$ 668,673,700$ (2106 $\$ / k W)$.

The levelized cost of electricity (COE) was calculated for both the reference plant and the $\mathrm{O}_{2}$-fired plant. The COE value is made up of contributions from the capital cost, operating and maintenance costs, consumables, and fuel costs. The levelized COE was calculated to be $4.61 \mathrm{\Phi} / \mathrm{kWh}$ for the reference plant and to be $6.41 \mathrm{c} / \mathrm{kWh}$ for the $\mathrm{O}_{2} \mathrm{PC}$ plant. The $\mathrm{CO}_{2}$ mitigation cost (MC) of the $\mathrm{O}_{2}-\mathrm{PC}$ plant was calculated at $21.4 \$$ /tonne.

Compared to the COE of the $\mathrm{O}_{2} \mathrm{PC}$, the COE for the other technologies is $45 \%$ higher for Air PC, 40\% higher for NGCC, and 6\% higher for IGCC. Compared to the $\mathrm{MC}$ of the $\mathrm{O}_{2} \mathrm{PC}$, the $\mathrm{MC}$ for the other technologies is $250 \%$ higher for NGCC, 160\% higher for Air PC, and 17\% higher for IGCC. 


\subsection{Experimental}

This work performed for this report was performed utilizing computer program simulations. No experimental equipment was used. 


\subsection{Results and Discussion}

\subsection{Main Assumptions}

The economic analysis was carried out based on the EPRI Technical Assessment Guide (TAG) methodology. Plant capital costs were compiled under the Code of Accounts developed by EPRI and used in references [1] and [2].

The estimate basis and major assumptions are listed below:

- Total plant costs are estimated in January 2004 dollars.

- Plant book life is 20 years.

- The net power output for the reference PC plant (without $\mathrm{CO}_{2}$ sequestration) is $450 \mathrm{MWe}$ and for the $\mathrm{O}_{2} \mathrm{PC}$ plant (with sequestration) is $327 \mathrm{MWe}$.

- Capacity factor is $85 \%$. The plant will operate at $100 \%$ load at $85 \%$ of the time.

- Cost of electricity (COE) was determined on a levelized constant dollar basis.

- Average annual ambient air conditions for material balances, thermal efficiencies and other performance related parameters are at a dry bulb temperature of $60 \mathrm{deg}$. $\mathrm{F}$ and an air pressure of $14.7 \mathrm{psia}$.

- The coal is Illinois \#6 coal (see Table 1 for analysis).

- Terms used are consistent with the EPRI TAG.

\subsection{Plant Cost Basis}

The total plant cost (TPC), also referred to as the plant capital cost is comprised of the following elements:

1. Bare erected plant cost.

2. Overheads and fee for engineering and home office.

3. Project and process contingencies. 
The $\mathrm{O}_{2}$-fired PC plant capital costs were derived in comparison to a recently constructed Foster Wheeler reference plant, which is an existing subcritical pressure, natural circulation PC plant.

The major changes to the reference plant were:

- Redesigned boiler (boiler size, and heat transfer surface) (see Ref. 3)

- Air pre-heater removed

- Added new flue gas-to-recycle gas heat exchanger

- Reduced size of FD and ID boiler fans

- Reduced weight of primary and secondary oxidant ductwork

- Removed plant selective catalytic NOx reduction (SCR) system

- Removed plant flue gas desulfurization (FGD) system

- Replaced full size plant stack with start-up stack

- Added air separation unit

- Added $\mathrm{CO}_{2}$ compression and dehydration unit

For the modified components, the plant capital costs were calculated as cost differentials by the Foster Wheeler estimating department. These cost differentials were then added to the base cost of the reference plant.

For the new components costs were either obtained from vendor quotes and/or determined by the Foster Wheeler estimating department as follows:

- The ASU cost was obtained from Air Products and Chemicals Inc.

- The $\mathrm{CO}_{2}$ compression and de-hydration system costs were developed using internal data from a Foster Wheeler commercial project. This price was compared to a recent estimate by Nexant Inc. (Ref. 4) for confirmation.

- The flue gas-to-recycle gas heat exchanger cost was estimated by Foster Wheeler based on internal cost data for similar units.

Allowance for engineering and home office overheads and fee of $6 \%$ of the bare erected cost was added for the new components. The "bare erected cost" is the installed cost of the equipment and systems that make up the plant.

For the new plant items, project contingencies were added to account for the uncertainty based on the level of detail currently available (or lacking) in the design. Consistent with EPRI Technical Assessment Guide (TAG), a 15\% (of bare erected cost) project contingency was used for the $\mathrm{CO}_{2}$ compression and de-hydration system, and a 5\% project contingency was used for the ASU. No process contingencies were applied, since the components of the new systems (e.g. compressors, knock-out pots, etc.) are well-developed technologies.

Table 2 shows the capital cost worksheet for the $\mathrm{O}_{2}$ fired PC plant. As the table shows, a total plant cost of $\$ 668,673,700.00$, or $2106 \$ / \mathrm{kW}$ was calculated. 
Table 1 - Coal Properties

\begin{tabular}{|r|c|r|}
\hline Illinois No. 6 Coal & & \\
\hline $\mathrm{C}$ & $\%$ & $63.75 \%$ \\
\hline $\mathrm{H}$ & $\%$ & $4.50 \%$ \\
\hline $\mathrm{O}$ & $\%$ & $6.88 \%$ \\
\hline $\mathrm{N}$ & $\%$ & $1.25 \%$ \\
\hline $\mathrm{Cl}$ & $\%$ & $0.29 \%$ \\
\hline $\mathrm{S}$ & $\%$ & $2.51 \%$ \\
\hline $\mathrm{Ash}$ & $\%$ & $9.70 \%$ \\
\hline $\mathrm{H} 2 \mathrm{O}$ & $\%$ & $11.12 \%$ \\
\hline Total & $\%$ & $100.00 \%$ \\
\hline & & \\
\hline LHV & $\mathrm{Btu} / \mathrm{lb}$ & 11,283 \\
\hline $\mathrm{HHV}$ & $\mathrm{Btu} / \mathrm{lb}$ & 11,631 \\
\hline
\end{tabular}




\section{Table 2 - Oxygen-Fired PC Plant Capital Cost Estimate}

Base Plant: Air-Fired subcritical pressure, natural circulation PC

Base Plant Output:

$450 \mathrm{MWe}$, net

Base Plant "As bid" cost: $\quad \$ 585,000,000.00$ Includes contingencies and EPC costs

Cost differences in converting air-fired PC to the oxygen-fired PC configuration:

\begin{tabular}{|c|c|c|c|c|c|c|c|c|}
\hline \multirow{2}{*}{\begin{tabular}{|l} 
Item \\
\end{tabular}} & \multirow{3}{*}{\begin{tabular}{|c|}
\multicolumn{2}{|c|}{ Description of change } \\
Furnace panels change from carbon steel to alloy steel \\
\end{tabular}} & & \multirow{3}{*}{\begin{tabular}{|c|} 
Eng'g CM \\
HO \& Fee \\
Incl As bid
\end{tabular}} & \multicolumn{4}{|c|}{ Contingencies } & \multirow{2}{*}{$\begin{array}{l}\text { Total Plant } \\
\text { Cost }\end{array}$} \\
\hline & & Bare erected cost & & & ess & & Project & \\
\hline \multirow{9}{*}{ Boiler } & & $\$ \quad 600,000.00$ & & $\$$ & - & $\$$ & - & $600,000.00$ \\
\hline & Less HRA surface needed & $(306,000.00)$ & Incl. As bid & $\$$ & - & $\$$ & - & $(306,000.00)$ \\
\hline & Smaller economizer & $(600,000.00)$ & Incl. As bid & $\$$ & - & $\$$ & - & $(600,000.00)$ \\
\hline & Air pre-heater not required & $(4,600,000.00)$ & Incl. As bid & $\$$ & - & $\$$ & - & $(4,600,000.00)$ \\
\hline & New Flue-gas/recycle gas heat exchanger & $\$ 6,000,000.00$ & Incl. As bid & $\$$ & - & $\$$ & - & $6,000,000.00$ \\
\hline & Less oxidant and gas ductwork & $\$(1,000,000.00)$ & Incl. As bid & $\$$ & - & $\$$ & - & $(1,000,000.00)$ \\
\hline & SCR system not required & $\$(6,400,000.00)$ & Incl. As bid & $\$$ & - & $\$$ & - & $(6,400,000.00)$ \\
\hline & Smaller FD and ID boiler fans & $\$(2,200,000.00)$ & Incl. As bid & $\$$ & - & $\$$ & - & $(2,200,000.00)$ \\
\hline & Less boiler structural steel (smaller boiler) & $\$(2,000,000.00)$ & Incl. As bid & $\$$ & - & $\$$ & - & $\$(2,000,000.00)$ \\
\hline \multirow{2}{*}{ BOP } & FGD sytem not required & $\$(56,000,000.00)$ & Incl. As bid & $\$$ & - & $\$$ & - & $\$(56,000,000.00)$ \\
\hline & Full size stack replaced by small, start-up stack & $\$(6,000,000.00)$ & Incl. As bid & $\$$ & - & $\$$ & - & $\$(6,000,000.00)$ \\
\hline ASU & Air separation unit added & $\$ 116,970,000.00$ & $\$ 7,018,200.00$ & $\$$ & - & & $5,848,500.00$ & $\$ 129,836,700.00$ \\
\hline CO2 System & CO2 compression and dehydration unit added & $\$ 38,300,000.00$ & $\$ 2,298,000.00$ & $\$$ & - & & $5,745,000.00$ & $\$ 46,343,000.00$ \\
\hline & Total difference: & $\$ 82,764,000.00$ & $\$ 9,316,200.00$ & $\$$ & - & & $1,593,500.00$ & $\$ 103,673,700.00$ \\
\hline
\end{tabular}

O2 PC Plant Cost:

$\$ \quad 688,673,700.00 \quad 2,106 \$ / k W$

O2 PC Plant net output:

$327 M W$ 


\subsection{Total Plant Investment (TPI)}

To determine the total investment required at the date of start-up, the TPC is escalated by the average interest rate over the construction period. Unlike the TPC, which assumes instantaneous construction, TPI ensures that escalation of construction costs and allowance for funds used during construction is properly taken into account. The construction period was estimated to be 4 years. Assuming uniform cash flow over the construction period, the TPI was calculated as follows:

$\mathrm{TPI}=\mathrm{TPC}\left[1+\mathrm{i}_{\mathrm{avg}}\right]$

Where

$$
\begin{aligned}
\mathrm{i}_{\mathrm{avg}} & =\text { Average interest rate over construction period } \\
& =(\text { Interest rate })(\text { Construction Period in Years }) / 2=10 \%
\end{aligned}
$$

The annual interest rate was taken as 5\%.

\subsection{Total Capital Requirement (TCR)}

The TCR includes all capital required to complete the project. TCR is the sum of TPI, pre-paid royalties, pre-production (start-up) costs, inventory capital, and land cost:

- Royalties costs are assumed inapplicable to the $\mathrm{CO}_{2}$ hybrid plant

- Pre-production costs cover operator training, equipment checkout, major changes in plant equipment, extra maintenance, and inefficient use of fuel and other materials during start-up. They are estimated as follows:

- 1 month of fixed operating costs, operating and maintenance labor, administrative and support labor, and maintenance materials.

- $\quad 1$ month of variable operating costs at full capacity (excluding fuel) - includes chemicals, water, and other consumables and waste disposal charges.

- $\quad 25 \%$ of full capacity fuel cost for 1 month - covers inefficient operation that occurs during the start-up period.

- $\quad 2 \%$ of TPI - covers expected changes and modifications to equipment that will be needed to bring the plant up to full capacity.

- Inventory capital is the capital required for initial inventories of fuel and other consumables, which are capitalized and included in the inventory capital account. Fuel and other consumables inventory (except water) are based on full-capacity operation for 15 days. An allowance of $1 / 2$ percent of the TPC equipment cost is included for spare parts. 
- Initial catalyst and chemical charge covers the initial cost of any catalysts or chemicals that are contained in the process equipment, but not in storage. In this study, this small charge was included with the equipment capital costs and is a part of the TPC.

- Land cost is based on 60 acres at $\$ 10,000 /$ acre.

The TPI and the TCR cost components are shown on Table 6 and Table 7.

\subsection{Operating Costs And Expenses}

Operating costs were expressed in terms of the following categories:

- Operating Labor

- Maintenance Cost

- Maintenance labor

- Maintenance materials

- Administrative and Support Labor

- Consumables

- Fuel Cost

These values were calculated in consistence with EPRI TAG methodology. All costs were based on a first year basis with January 2004 dollars. The first year costs do not include start-up expenses, which are included in the TCR.

The cost categories listed above are calculated, on a dollars per year basis, as follows:

- Operating labor is calculated by multiplying the number of operating personnel with the average annual (burdened) compensation per person.

- Maintenance costs are estimated to be $2 \%$ of the TPC and are divided into maintenance labor and maintenance materials

- Maintenance labor is estimated to be $40 \%$ of the total maintenance cost

- Maintenance materials are estimated to be $60 \%$ of the total maintenance cost

- Administrative and support labor is estimated to be equal to $25 \%$ of the sum of operating and maintenance labor.

- Consumables are feedstock and disposal costs calculated from the annual usage at $100 \%$ load and $85 \%$ capacity factor. The costs is expressed in year 2004 dollars and levelized over 20 years on constant dollar basis. 
- Fuel cost is calculated based on the assumed net cost for delivered coal, which is $\$ 1.14 / \mathrm{MMBtu}[5]$. Fuel cost is determined on a first year basis and levelized over 20 years on a constant dollar basis. The calculation of first year fuel costs is done as follows:

Fuel (tons/day) $=($ Plant Heat Rate) $\times$ (net capacity in $\mathrm{kW}$ ) $\times 24 \mathrm{hr} /$ day HHV x $2000 \mathrm{lb} / \mathrm{ton}$

Fuel Unit Cost (\$/ton) = HHV x $2000 \mathrm{lb} /$ ton x (Fuel Cost in $\$ /$ MMBtu) $\times 10^{6}$

Fuel Cost $\left(1^{\text {st }}\right.$ year $)=$ Fuel (tons/day) x Fuel Unit Cost $(\$ /$ ton $)$ x 365 day/yr x $0.85(C F)$

The operating and maintenance costs, excluding fuel and consumables, are combined and divided into two components: 1) Fixed O\&M, which is independent of power generation, and 2) Variable O\&M, which is proportional to power generation. These are calculated as follows:

Fixed O\&M (\$/yr) = Oper. Labor + Maint. Labor + Adm. and Support Labor

Fixed O\&M $(\$ / \mathrm{kW}-\mathrm{yr})=\frac{\text { Fixed O\&M }(\$ / \text { year })}{\text { Net Power }(\mathrm{kW})}$

Variable O\&M (\$/yr) = Maintenance Materials

Variable O\&M $(\$ / k W h)=\frac{\text { Variable O\&M }(\$ / y r)}{\text { Net Power }(\mathrm{kW}) \times \text { CF x } 8760}$

Where, CF is the plant capacity factor and 8760 is the total number of hours in one year.

The operating and maintenance costs for the $\mathrm{O}_{2}$-fired PC and the air-fired reference plant are shown on Table 3 . The "total production cost" shown at the bottom of the table expresses the charge of operating and maintaining the baseline plant (including fuel and consumable costs) in terms of cents per kilowatt-hour.

\subsection{Cost Of Electricity (COE)}

The COE value is made up of contributions from the capital cost (called the carrying charge), operating and maintenance costs, consumables, and fuel costs. The following relationship is used to calculate COE from these cost components:

COE $=$ LCC + LFOM $\times 100 /(8760 \times$ CF $)+L V O M+L C M+L F C$

LCC $=$ Levelized carrying charge, $\$ / \mathrm{kWh}$ 
LFOM = Levelized fixed O\&M, $\$ / \mathrm{kW}$-yr

LVOM $=$ Levelized variable O\&M, $\$ / \mathrm{kWh}$

$\mathrm{LCM}=$ Levelized consumables, $\$ / \mathrm{kWh}$

LFC = Levelized fuel costs, $\$ / \mathrm{kWh}$

$\mathrm{CF}=$ plant capacity factor $(0.85)$

The basis for calculating the capital investment and revenue requirements for the reference plant and the $\mathrm{O}_{2} \mathrm{PC}$ are given in Table 4 and Table 5, respectively. The capital investment and revenue requirements summary is given in Table 6 for the reference plant without $\mathrm{CO}_{2}$ sequestration and in Table 7 for the $\mathrm{O}_{2} \mathrm{PC}$.

As Table 6 and Table 7 show, the levelized COE for $85 \%$ capacity factor was calculated at $4.61 \Phi / \mathrm{kWh}$ without $\mathrm{CO}_{2}$ sequestration and at $6.41 \Phi / \mathrm{kWh}$ with $\mathrm{CO}_{2}$ sequestration.

\subsection{Comparison with Other Technologies}

An economic comparison was performed between the $\mathrm{O}_{2} \mathrm{PC}$ and other competing $\mathrm{CO}_{2}$ removal technologies. For comparison the following alternate technologies were chosen:

Air PC: $\quad$ Supercritical PC plant with post-combustion $\mathrm{CO}_{2}$ mitigation (Ref [1] case 7A).

NGCC: Natural Gas Combined Cycle with post combustion (Ref [1] case $1 \mathrm{~A})$.

IGCC: Integrated Gasification Combined Cycle with pre-combustion $\mathrm{CO}_{2}$ mitigation (Ref. [2] case 3E).

The economics of these technologies were compared with the $\mathrm{O}_{2} \mathrm{PC}$ using both the levelized cost of electricity and the $\mathrm{CO}_{2}$ mitigation cost as indexes. The $\mathrm{CO}_{2}$ mitigation cost (MC) shows the cost impact, in dollars per tonne of $\mathrm{CO}_{2}$ that would otherwise be emitted, of a configuration that allows $\mathrm{CO}_{2}$ capture relative to the reference plant.

The MC is calculated as follows:

$$
M C=\frac{C O E_{\text {with removal }}-C O E_{\text {reference }}}{E_{\text {reference }}-E_{\text {with removal }}} \times 0.01 \$ / \Phi
$$

COE $=$ Cost of electricity in $\$ / k W h$

$\mathrm{E}=\mathrm{CO}_{2}$ emission in tonnes $/ \mathrm{kWh}$

The COE and MC for the Air PC, NGCC, and IGCC were obtained from Ref. 1 and Ref. 2. Since the economic analysis of Ref. 1 and Ref. 2 were made in 2000 
two adjustments were necessary so that the values can be compared to the results of the current $\mathrm{O}_{2} \mathrm{PC}$ economic analysis:

1. A constant inflation rate of $2 \%$ was assumed between 2000 and 2004 .

2. The 2000 natural gas fuel price was replaced with the 2004 natural gas fuel price (fuel price increase is $118 \%$ ).

Since the analyses of Ref. 1 and Ref. 2 were assumed at a 65\% capacity factor, Figure 1 and Figure 2 present a comparison of the COE and MC using a 65\% capacity factor for the $\mathrm{O}_{2} \mathrm{PC}$. Compared to the COE of the $\mathrm{O}_{2} \mathrm{PC}$, the COE for the other technologies is 17\% higher for Air PC, 15\% higher for NGCC, and $14 \%$ lower for IGCC. Compared to the MC of the $\mathrm{O}_{2} \mathrm{PC}$, the $\mathrm{MC}$ for the other technologies is $170 \%$ higher for NGCC, $100 \%$ higher for Air PC, and $9 \%$ lower for IGCC.

Since the $\mathrm{O}_{2} \mathrm{PC}$ uses reliable long-proven technology it is expected that the capacity factor of the $\mathrm{O}_{2}$ PC will be close to $85 \%$. Consequently Figure 3 and Figure 4 present a comparison of the COE and $\mathrm{MC}$ using an $85 \%$ capacity factor for the $\mathrm{O}_{2} \mathrm{PC}$. Compared to the COE of the $\mathrm{O}_{2} \mathrm{PC}$, the COE for the other technologies is $45 \%$ higher for Air PC, 40\% higher for NGCC, and 6\% higher for IGCC. Compared to the $\mathrm{MC}$ of the $\mathrm{O}_{2} \mathrm{PC}$, the $\mathrm{MC}$ for the other technologies is $250 \%$ higher for NGCC, 160\% higher for Air PC, and 17\% higher for IGCC.

Note that the air-fired post combustion capture PC plant data used in Figure 1 to Figure 4 is for a supercritical unit whereas the $\mathrm{O}_{2}$ PC plant operates at subcritical pressure. It is expected that the economic cost (COE and $\mathrm{MC}$ ) of a supercritical $\mathrm{O}_{2} \mathrm{PC}$ will be lower than a subcritical $\mathrm{O}_{2} \mathrm{PC}$. 


\section{Table 3 - Operating, Maintenance and Fuel Costs for the $\mathrm{O}_{2} \mathrm{PC}$ and the Air- fired Reference}

\author{
1) With $\mathrm{CO} 2$ Sequestration (O2 PC)

$\begin{array}{lc}\text { Plant Net Power = } & 326 \mathrm{MW} \\ \text { Capacity Factor } & 85 \% \\ \text { Operating and Maintenance Costs } & \end{array}$

Operating labor

Maintenance Cost

Maintenance Labor (40\%)

Maintenance Materials (60\%)

Administrative Support and Labor

$2 \%$ of TPC

60 people

\begin{tabular}{|c|c|c|}
\hline \multirow{2}{*}{$\begin{array}{l}\text { Unit Cost } \\
\$ 90,000.00\end{array}$} & \$lyear & \$/KW-yr \\
\hline & $\$ 5,400,000.00$ & $\$ 16.56$ \\
\hline & $\$ 5,509,389.60$ & $\$ 16.90$ \\
\hline & $\$ 8,264,084.40$ & $\$ 25.35$ \\
\hline & $\$ 2,727,347.40$ & $\$ 8.37$ \\
\hline Unit Cost & \$lyear & c/KWh \\
\hline$\$ 0.80$ & $\$ 2,005,411$ & 0.070 \\
\hline$\$ 0.16$ & $\$ 970,619$ & 0.034 \\
\hline & $\$ 50,000.00$ & 0.002 \\
\hline$\$ 30$ & $\$ 189,000.00$ & 0.007 \\
\hline$\$ 10$ & $\$ 1,359,639.60$ & 0.048 \\
\hline & $\$ 330,000.00$ & 0.012 \\
\hline & & 0.160 \\
\hline Btu/kWh & & \\
\hline Unit Coc & \$lyear & \\
\hline$\$ 1.14$ & $\$ 31,577,905$ & 1.301 \\
\hline
\end{tabular}

Total Production Cost
8080 kgals/day
19553 lbs/day

Water Chemicals

Limestone

Start-up Fuel

Startup Electricity

Other Chemicals

$\underline{\text { Fuel Cost (2004 Dollars) }}$

Heat Rate $=$
Ash disposal
$6300 \mathrm{MWh} / \mathrm{yr}$

$18.26 \mathrm{ton} / \mathrm{hr}$

$$
\begin{array}{lr}
\text { Rate }= & 11,411 \\
& \begin{array}{r}
\text { Btu/kWh } \\
\text { Unit Cost }
\end{array} \\
3720.11 \text { MMBtus/hr } & \$ 1.14
\end{array}
$$

$\$ 31,577,905$
1.301

$2.36 \mathrm{c} / \mathrm{kWh}$

2) Without CO2 Sequestration (Air-fired reference)

Plant Net Power =

Capacity Factor

Operating and Maintenance Costs

Operating labor
Maintenance Cost
$\quad 2 \%$ of TPC
$\quad$ Maintenance Labor (40\%)
$\quad$ Maintenance Materials (60\%)
Administrative Support and Labor $25 \%$ of O\&M Labor
Consumable Operating Costs (Except Fuel)

Water

Water Chemicals

Limestone

Start-up Fuel

Startup Electricity

Ash disposal

Fuel Cost (2004 Dollars)

$$
\begin{gathered}
7906 \mathrm{kgals} / \mathrm{day} \\
19133 \mathrm{lbs} / \mathrm{day} \\
432 \text { tons/day } \\
5 \text { starts/year } \\
6300 \mathrm{MWh} / \mathrm{yr} \\
52.43 \mathrm{ton} / \mathrm{hr}
\end{gathered}
$$

\begin{tabular}{|c|c|c|}
\hline \multirow{2}{*}{$\begin{array}{l}\text { Unit Cost } \\
\$ 90,000.00\end{array}$} & \$lyear & $\$ / K W-y r$ \\
\hline & $\$ 5,040,000.00$ & $\$ 15.46$ \\
\hline & $\$ 4,680,000.00$ & $\$ 14.36$ \\
\hline & $\$ 7,020,000.00$ & $\$ 21.53$ \\
\hline & $\$ 2,430,000.00$ & $\$ 7.45$ \\
\hline Unit Cost & \$lyear & c/KWh \\
\hline$\$ 0.80$ & $\$ 1,962,269$ & 0.054 \\
\hline$\$ 0.16$ & $\$ 949,738$ & 0.026 \\
\hline$\$ 15$ & $\$ 2,010,420$ & 0.055 \\
\hline & $\$ 50,000.00$ & 0.001 \\
\hline$\$ 30$ & $\$ 189,000.00$ & 0.005 \\
\hline$\$ 10$ & $\$ 3,903,937.80$ & 0.107 \\
\hline & & 0.248 \\
\hline Btu/kWh & & \\
\hline Unit Cost & \$/year & $\mathrm{c} / \mathrm{KWh}$ \\
\hline$\$ 1.14$ & $\$ 32,926,353$ & 1.060 \\
\hline
\end{tabular}

Heat Rate $=$

9,302

3878.96 MMBtus/hr
$2.10 \mathrm{c} / \mathrm{kWh}$ 


\section{Table 4 - Estimate Basis/Financial Criteria for Revenue Requirement Calculations: Air-fired Reference Plant}

\section{GENERAL DATA/CHARACTERISTICS}

Plant Type:

Plant Size:

Location:

Fuel: Primary/Secondary

Energy from Primary/Secondary Fuels:

Levelized Capacity Factor / Preproduction (equivalent months):

Capital Cost Year Dollars (Reference Year Dollars):

Delivered Cost of Primary/Secondary Fuel:

Design/ Construction Period:

Plant Start-up Date (1st year Dollars):

Land Area/Unit Cost:

\section{FINANCIAL CRITERIA}

Project Book Life:

Book Salvage Value:

Project Tax Life:

Tax Depreciation Method:

Inflation Rate

Property Tax Rate:

Insurance Tax Rate:

Federal Income Tax Rate:

State Income Tax Rate:

Investment Tax Credit/\% Eligible

Economic Basis:

Capital Structure Common Equity

Preferred Stock

Debt

Weighted Cost of Capital: (after tax)
Air-fired Subcritical PC

$450 \mathrm{MW}$, net

Sea Level, Middletown USA

Illinois \#6

$\begin{array}{ccc}9,302 \mathrm{Btu} / \mathrm{kWh} & -- & \text { Btu/kWh } \\ 85 \% & & 1 \text { months }\end{array}$

2004 (January)

1.14 \$/MBtu
4 years
60 acres
$\quad \$ 10,000$ / Acre

20 years

- $\%$

20 years

Accel. Based on ACRS Class

$$
2.0 \%
$$

$1.0 \%$

$1.0 \%$

$34.0 \%$

$4.2 \%$

- $\%$ - $\%$

Over Book Constant Dollars

$\begin{array}{rrr}\text { \% of Total } & & \text { Cost(\%) } \\ 40 & & 12 \\ 0 & & 8.5 \\ 60 & 7.456 \% & 7\end{array}$




\section{Table 5 - Estimate Basis/Financial Criteria for Revenue Requirement Calculations: $\mathrm{O}_{2}$-fired Reference Plant}

\section{GENERAL DATA/CHARACTERISTICS}

Plant Type:

Plant Size:

Location:

Fuel: Primary/Secondary

Energy from Primary/Secondary Fuels:

Levelized Capacity Factor / Preproduction (equivalent months):

Capital Cost Year Dollars (Reference Year Dollars):

Delivered Cost of Primary/Secondary Fuel:

Design/ Construction Period:

Plant Start-up Date (1st year Dollars):

Land Area/Unit Cost:

\section{FINANCIAL CRITERIA}

Project Book Life:

Book Salvage Value:

Project Tax Life:

Tax Depreciation Method:

Inflation Rate:

Property Tax Rate:

Insurance Tax Rate:

Federal Income Tax Rate:

State Income Tax Rate:

Investment Tax Credit/\% Eligible

Economic Basis:

Capital Structure Common Equity Preferred Stock Debt

Weighted Cost of Capital: (after tax)
Oxygen Fired Subcritical PC $327 \mathrm{MW}$, net

Sea Level, Middletown USA

Illinois \#6

11,411 Btu/kWh -Btu/kWh

$85 \%$ 1 months

2004 (January)

1.14 \$/MBtu -- \$/MBtu

4 years

2008 (January)

$$
60 \text { acres } \$ 10,000 / \text { Acre }
$$

20 years

- $\%$

20 years

Accel. Based on ACRS Class

$2.0 \%$

$1.0 \%$

$1.0 \%$

$34.0 \%$

$4.2 \%$

- $\%$ - $\%$

Over Book Constant Dollars

\begin{tabular}{rrr} 
\% of Total & & Cost(\%) \\
\cline { 3 - 3 } & & \\
0 & & 8.5 \\
60 & & 7
\end{tabular}




\section{Table 7 - Capital Investment and Revenue Requirement Summary: $\mathrm{O}_{2}$-fired Plant}

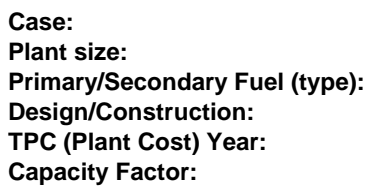

TOTAL CONSUMABLE OPERATING COST

\section{FUEL COST (1999 Dollars)}

\section{PRODUCTION COST SUMMARY}

Fixed O\&M

Variable O\&M

Consumables

By-product Credit

Fuel

TOTAL PRODUCTION COST

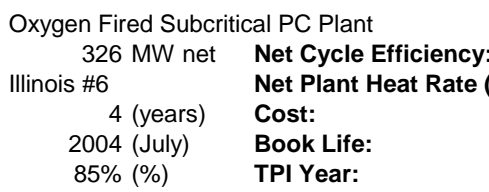

$29.90 \%$

11,411 (Btu/kWh)

1.14 (\$/MMBtu)

20 (years)

2004 (July) $3,652,640$ (tons/year)
$\$ / k W$

$2,048.4$ 28.6 35.6

$2,112.5$

$\begin{array}{lrrrr} & & \$ & 688,674 & 2,112.5 \\ \$ & 688,674 & & & \\ \$ & 68,867 & & & \end{array}$
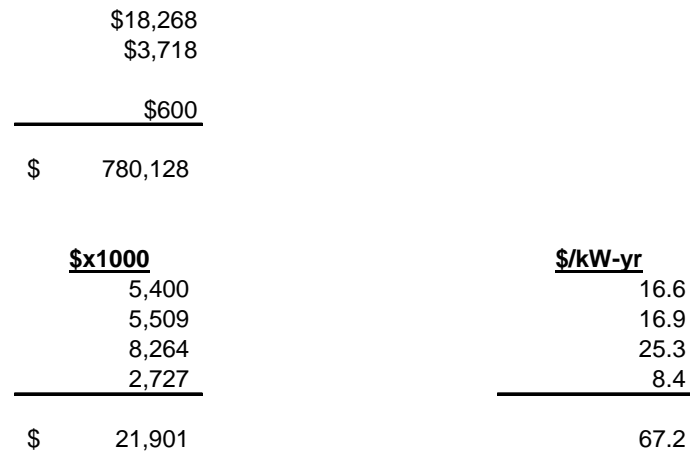

$\$$ / kW-yr

16.6

16.9

25.3

8.4

67.2

$41.83 \$ / k W-y r$

$0.34 \mathrm{c} / \mathrm{kWh}$

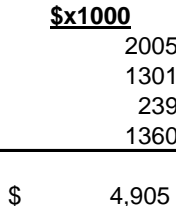

$\underline{c / k W h}$

0.07

$\$ \quad 31,578$

Levelized (Over Book Life \$) $\$$ /tonne CO2 avoided

2.03

1.36

(0.91)

2.86

5.34

16.08

21.42
0.05

0.01

0.05

0.17

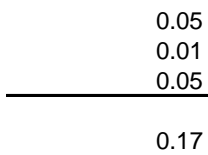

$\underline{\text { c/kWh }}$ 
Figure 1 - Comparison of Levelized Cost of Electricity Among Alternative Technologies $\left(\mathrm{O}_{2} \mathrm{PC}\right.$ with $\left.65 \% \mathrm{CF}\right)$

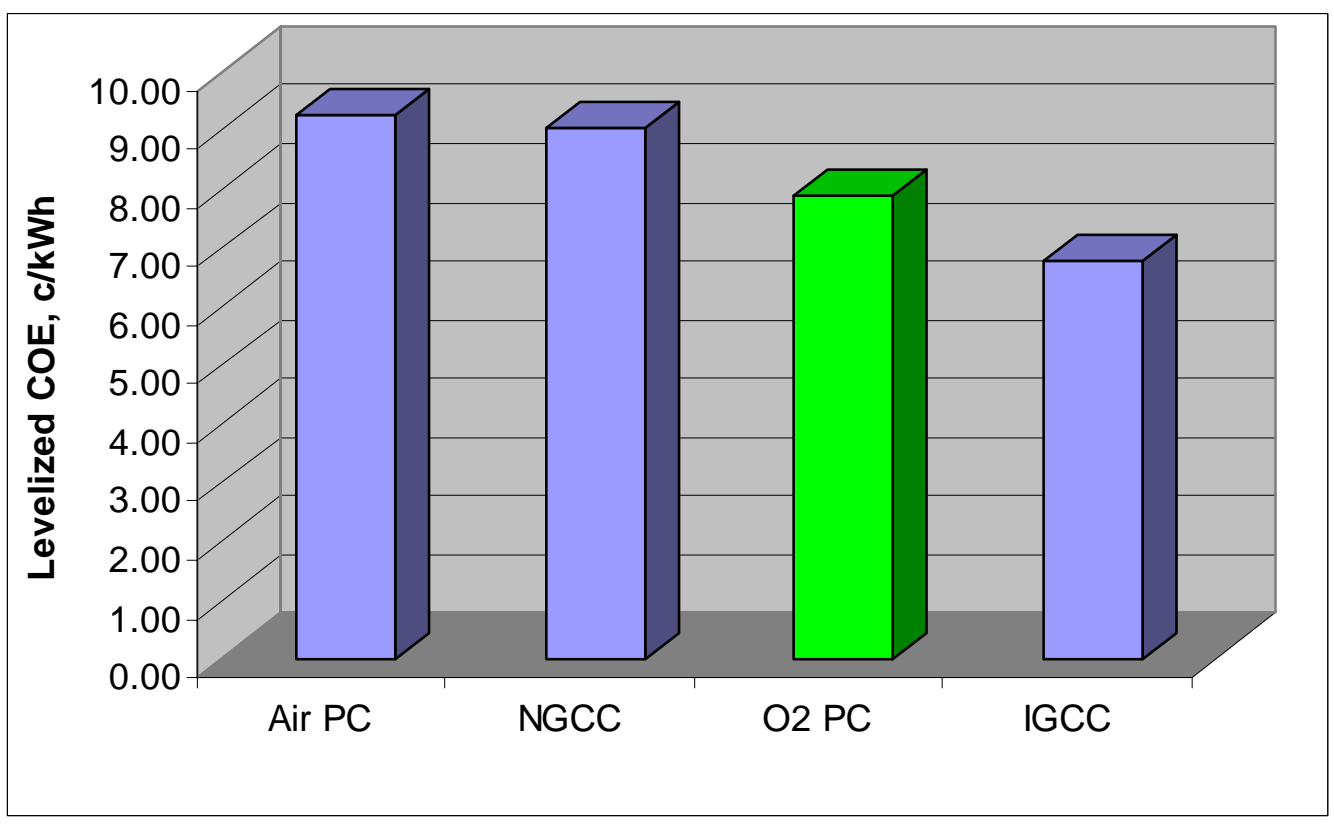

Figure 2 - Comparison of Mitigation Costs Among Alternative Technologies $\left(\mathrm{O}_{2} \mathrm{PC}\right.$ with $\left.65 \% \mathrm{CF}\right)$

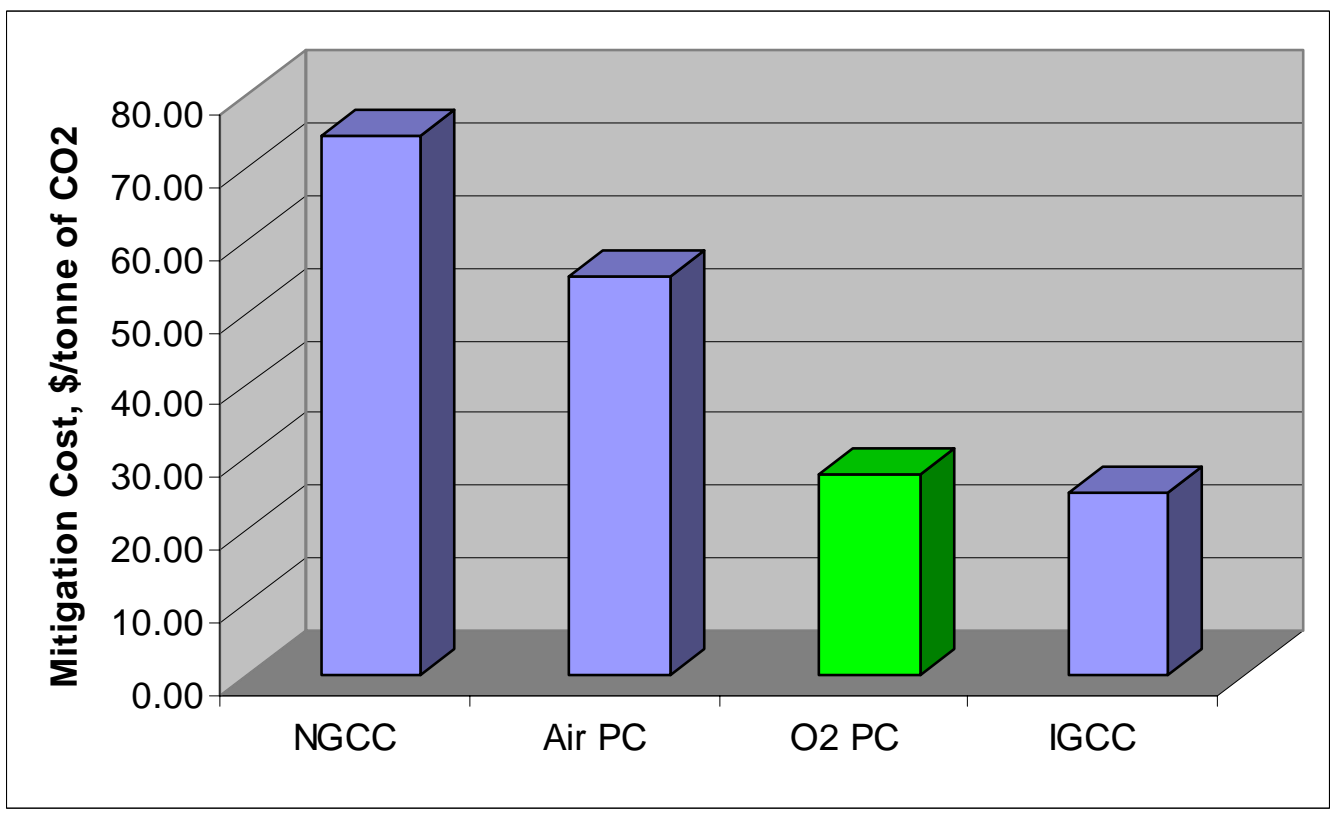


Figure 3 - Comparison of Levelized Cost of Electricity Among Alternative Technologies $\left(\mathrm{O}_{2} \mathrm{PC}\right.$ with $\left.85 \% \mathrm{CF}\right)$

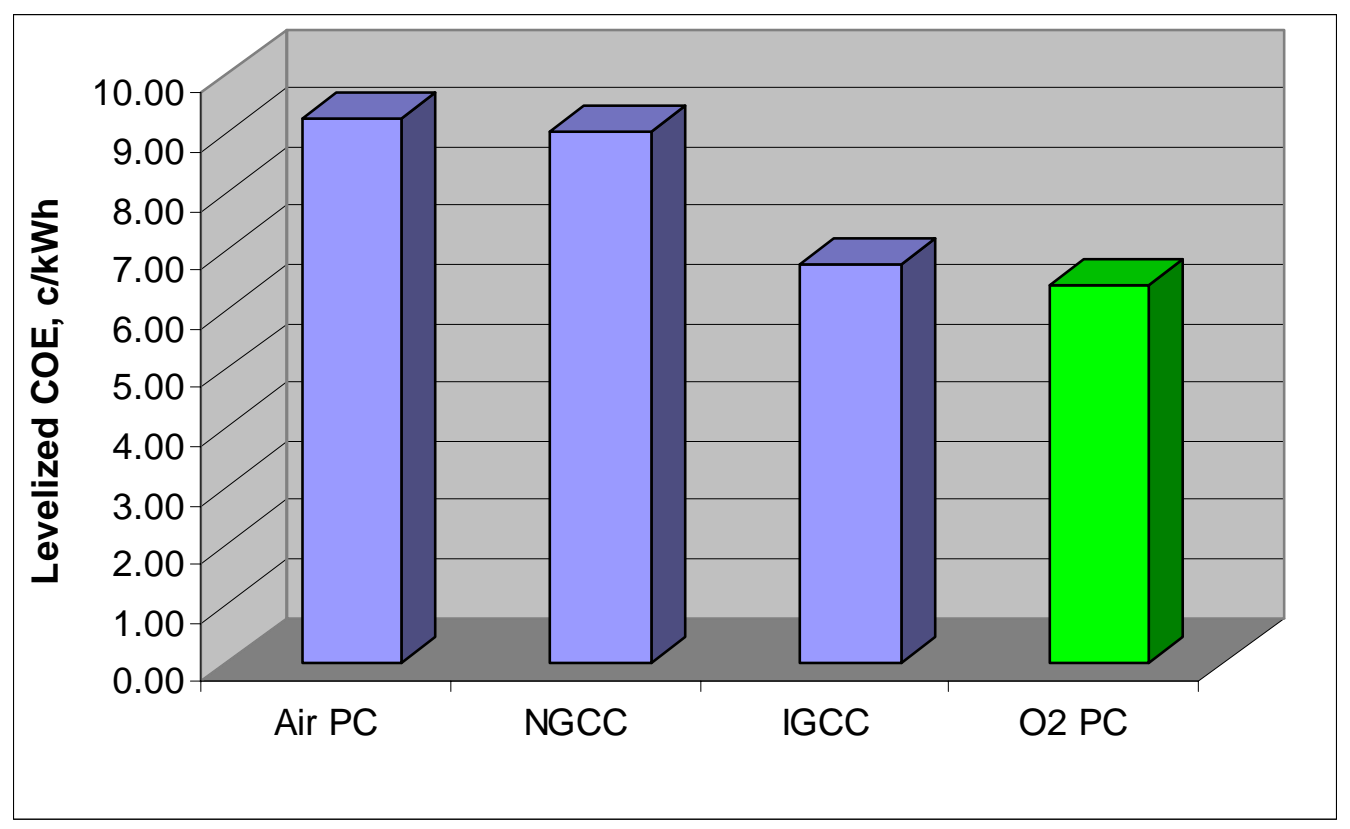

Figure 4 - Comparison of Mitigation Costs Among Alternative Technologies $\left(\mathrm{O}_{2} \mathrm{PC}\right.$ with $\left.85 \% \mathrm{CF}\right)$

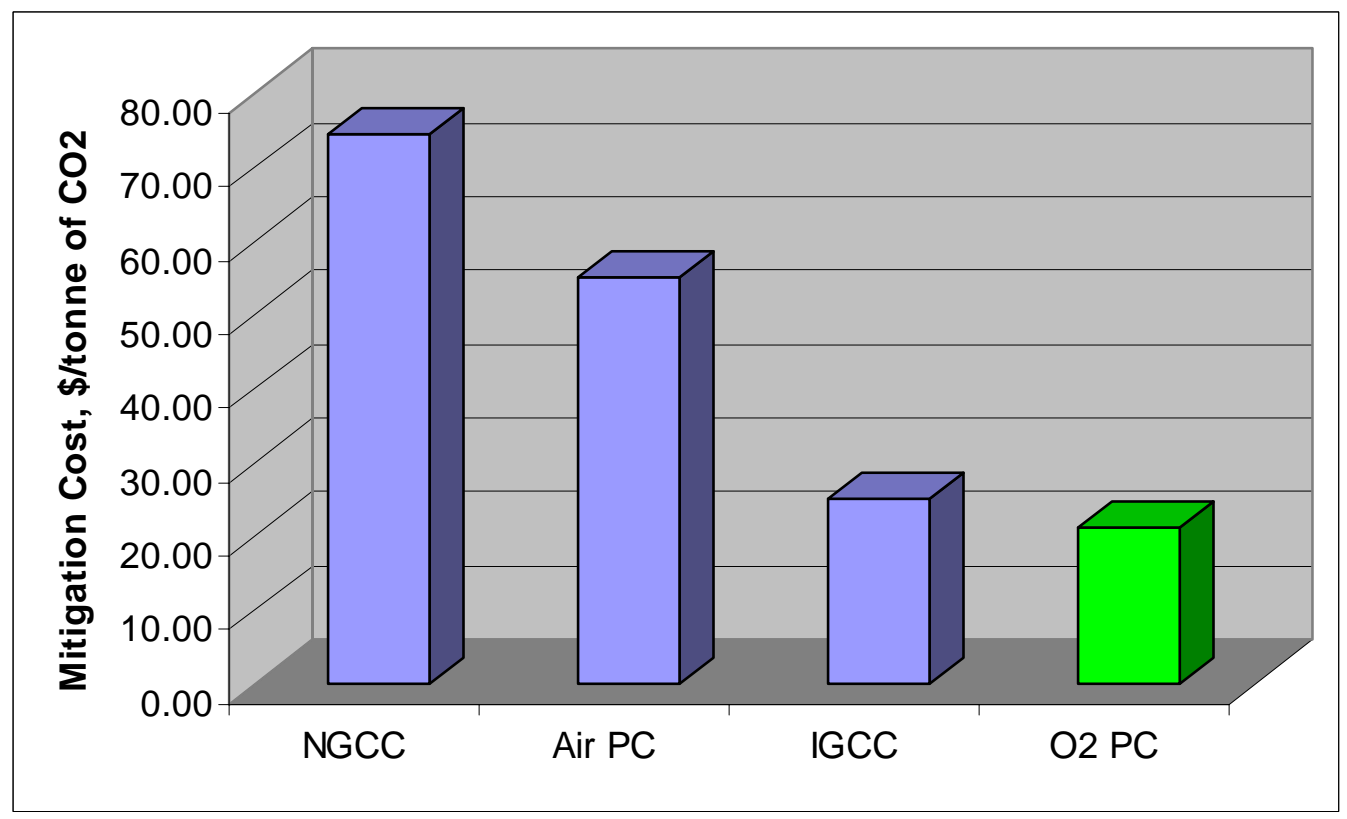




\subsection{Conclusion}

To assure continued U.S. power generation from its abundant domestic coal resources, new coal combustion technologies must be developed to meet future emissions standards, especially $\mathrm{CO}_{2}$ sequestration. Current conventional coalfired boiler plants burn coal using $15-20 \%$ excess air producing a flue gas, which is only approximately $15 \% \mathrm{CO}_{2}$. Consequently, $\mathrm{CO}_{2}$ sequestration requires noncondensable gases stripping, which is both expensive and highly powerconsumptive. Several different technologies for concentrating the $\mathrm{CO}_{2}$ by removing the non-condensable gases have been proposed including aminebased absorption and membrane gas absorption. However, these techniques require substantial energy, typically from low-pressure steam.

A new boiler is presented where the combustion air is separated into $\mathrm{O}_{2}$ and $\mathrm{N}_{2}$ and the boiler uses the $\mathrm{O}_{2}$, mixed with recycled flue gas, to combust the coal. The products of combustion are thus only $\mathrm{CO}_{2}$ and water vapor. The water vapor is easily condensed, yielding a pure $\mathrm{CO}_{2}$ stream ready for sequestration. The $\mathrm{CO}_{2}$ effluent is in a liquid form and is piped from the plant to the sequestration site. The combustion facility is thus truly a zero emission stackless plant.

The levelized cost of electricity (COE) was calculated to be $4.61 \$ / \mathrm{kWh}$ for the reference air-fired plant and to be $6.41 \mathrm{\$} / \mathrm{kWh}$ for the $\mathrm{O}_{2} \mathrm{PC}$ plant. The $\mathrm{CO}_{2}$ mitigation cost (MC) of the $\mathrm{O}_{2}-\mathrm{PC}$ plant was calculated at 21.4 \$/tonne.

Compared to the COE of the $\mathrm{O}_{2} \mathrm{PC}$, the COE for the other technologies is $45 \%$ higher for Air PC, 40\% higher for NGCC, and 6\% higher for IGCC. Compared to the $\mathrm{MC}$ of the $\mathrm{O}_{2} \mathrm{PC}$, the $\mathrm{MC}$ for the other technologies is $250 \%$ higher for NGCC, 160\% higher for Air PC, and 17\% higher for IGCC.

It is expected that the $\mathrm{COE}$ and $\mathrm{MC}$ of the $\mathrm{O}_{2} \mathrm{PC}$ will be reduced by the incorporation of new lower power-consuming air separation techniques, such as membrane separation and more advanced steam cycles such as supercritical and ultra-supercritical. In DOE contract, DE-FC26-04NT42207, FW will conduct a study to improve the efficiency and cost-effectiveness of the $\mathrm{O}_{2}$-based PC power plant through the incorporation of a high-temperature supercritical steam cycle and advanced $\mathrm{O}_{2}$ separation techniques. 


\subsection{References}

1. Evaluation of Innovative Fossil Fuel Power Plants with $\mathrm{CO}_{2}$ Removal, EPRI, Palo Alto, CA, U.S. Department of Energy - Office of Fossil Energy, Germantown, MD and U.S. Department of Energy/NETL, Pittsburgh, PA: 2000. 1000316

2. Updated Cost and Performance Estimates For Fossil Fuel Power Plants with $\mathrm{CO}_{2}$ Removal, EPRI, Palo Alto, CA, U.S. Department of Energy Office of Fossil Energy, Germantown, MD and U.S. Department of Energy/NETL, Pittsburgh, PA: 2002. 1004483.

3. Seltzer, Andrew, "Furnace and Heat Recovery Area Design and Analysis for Conceptual Design of Oxygen-Based PC Boiler" Task 4 Topical Report, January 2005, DE-FC26-03NT41736.

4. Gerard N. Choi, et al., "Cost Efficient Amine Plant Design for Post Combustion $\mathrm{CO}_{2}$ Capture from Power Plant Flue Gas", DOE/NETL 3rd Annual Conference on Carbon Sequestration, Alexandria, VA, May 3-6, 2004

5. Energy Information Administration/Electric Power Monthly, October 2004 


\subsection{List of Acronyms and Abbreviations}

$\begin{array}{ll}\text { ASU } & \text { Air separation unit } \\ \text { CF } & \text { Capacity Factor } \\ \text { COE } & \text { Cost or Electricity } \\ \text { E } & \text { Emission of } \mathrm{CO}_{2} \\ \text { EPRI } & \text { Electric Power Research Institute } \\ \text { FD } & \text { Forced draft } \\ \text { FGD } & \text { Flue gas de-sulfurization reactor } \\ \text { HHV } & \text { Higher heating value } \\ \text { ID } & \text { Induced draft } \\ \text { IGCC } & \text { Integrated gasification combined cycle } \\ \text { LCC } & \text { Levelized Carrying Charge } \\ \text { LCM } & \text { Levelized Consumables } \\ \text { LFC } & \text { Levelized Fuel Costs } \\ \text { LFOM } & \text { Levelized Fixed O\&M } \\ \text { LHV } & \text { Lower heating value } \\ \text { LVOM } & \text { Levelized Variable O\&M } \\ \text { MC } & \text { Mitigation Cost (CO }{ }_{2} \text { ) } \\ \text { NGCC } & \text { Natural gas combined cycle } \\ \text { NOx } & \text { Nitrogen oxides } \\ \text { O\&M } & \text { Operation and Maintenance } \\ \text { PC } & \text { Pulverized coal } \\ \text { SCR } & \text { Selective catalytic reactor } \\ \text { TCR } & \text { Total Capital Requirement } \\ \text { TPC } & \text { Total Plant Cost } \\ \text { TPI } & \text { Total Plant Investment }\end{array}$

